\title{
The Reality of Applying Human Resources Diversity Management and Its Impact on Workers' (Performance, Cooperation, Commitment and Loyalty): A Field Study on the Jordanian Food Industry Companies
}

\author{
Sahar Mohammad Abu Bakir ${ }^{1}$ \\ ${ }^{1}$ Associate Professor, Business Administration Department, Faculty of Business, Amman Arab University, Jordan \\ Correspondence: Sahar Mohammad Abu Bakir, Associate Professor, Business Administration Department, \\ Faculty of Business, Amman Arab University, Jordan. E-mail: saharbisan@yahoo.com
}

Received: December 19, 2016

Accepted: February 14, 2017

Online Published: February 17, 2017

doi:10.5539/ibr.v10n3p183

URL: https://doi.org/10.5539/ibr.v10n3p183

\begin{abstract}
Globalization, political instability, poverty, forced immigration and many other factors created a state of diversity in the composition of the world population, and accordingly diversity transferred into organizations, causing a big and unavoidable challenge to business organizations. Diverse human resources can be a source of success if they are well managed strategically, and could be the opposite if they were ignored, and don't have the needed inclusiveness.

This study aimed first to find out the degree to which the Jordanian food industry companies are engaged in Human Resources Diversity Management (DM) in terms of (equity and justice in applying human resources strategies), empowerment and religious freedom. And second to examine the influence of (DM) strategies on workers (performance, cooperation, commitment and loyalty), 150 of non-Jordanian workers at 5 companies operating at King Abdulla the second industrial city were surveyed, depending on the workers responses it was found that the 5 companies do engage in (DM) strategies, except for staffing which is restricted by the Jordanian Labor Law, the results of multiple regression showed that all DM strategies have an influence on workers performance.

Empowerment has only an influence on workers cooperation, and religious freedom affects workers commitment and loyalty.

The researcher recommended that more involvement in organizational activities, equity, justice and good treatment, will enhance workers cooperation, commitment and loyalty.
\end{abstract}

Keywords: commitment, cooperation, diversity management, human resources diversity, performance

\section{Introduction}

The notion (diversity) was close fitting with dissimilarity, differences between people since the creation of human being existed; gender, age, race, and religion were the oldest, in addition to a group of differences (education, years of experience, and position...etc ) are perceived extensively in business organizations recently (Shen, Chanda, D'netto \& Monga, 2009; Richter, 2014).

Many researchers tried to justify this alteration in the work place, according to Dessler(2014) changes in demographic features, Immigration, and globalization, were the main reasons. (Kemper, Bader, \& Froese 2016 ;Pant \& Vijaya V. 2015) inferred that it is difficult to recruit one kind of human resources; lately employees are flooded to organizations from different backgrounds, motivated by different expectations, they have mixed perceptions of themselves and varied understanding of others. It is not expected that those will dismiss their type of life, values, attitudes when they come to work ( Robbins \& Coulter, 2012; Ilmakunnas \& Ilmakunnas, 2011).

Jordan is not a way from diversity push and its consequences; in the last five years, as a result of migration from neighboring countries, Jordan has witnessed a marked increase in citizens' diversity in terms of number and quality, not just that, the workforce composition changed too; specifically in the manufacturing sector. 
So this paper aims first to find out if Jordanian food Industry companies are involved in managing diversity in a strategic manner, and the second objective is to explore the impact of diversity management strategies on workers (performance, cooperation, commitment and loyalty.

\section{Research Model and Variables}

Relying on the previous literature the researcher selected the study's variables as follows: The independent variable: (diversity management strategies) which was measured through equity and justice in applying human resources strategies (staffing, development, compensation and performance appraisal), empowerment and religious freedom. While the dependent variable: was measured through workers' performance (productivity and products quality), workers cooperation with their colleagues and with management, and workers loyalty and their commitment.

\section{Independent variable /s}

\section{Dependent variable /s}

\section{Diversity management strategies}

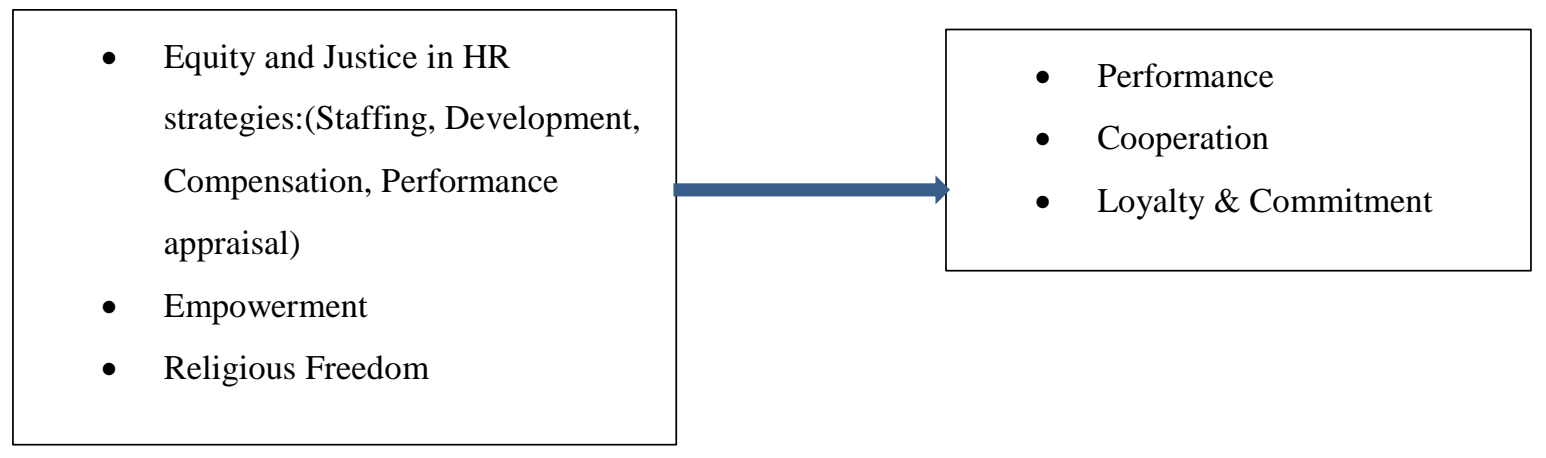

\subsection{Research Hypotheses}

Ho1: Jordanian food industry companies don't engage in diversity management strategies.

Ho2: Diversity management strategies (equity and Justice in HR strategies: staffing, development, compensation, performance appraisal), empowerment, and religious freedom have a positive influence on workers' (performance, cooperation, loyalty and commitment)

The following sub hypotheses derived from the main second hypothesis:

$\mathbf{H o 2}_{1}$ : Diversity management strategies have a positive influence on workers' performance.

$\mathbf{H o 2}_{2}$ Diversity management strategies have a positive influence on workers' cooperation.

$\mathbf{H o 2}_{3}$ Diversity management strategies have a positive influence on workers' loyalty\& commitment.

\section{Theoretical Background and Literature Review}

\subsection{Human Resources Diversity \& Diversity Dimensions}

There is no assent of what diversity encompasses; people can be categorized according to their noticeable features, or to their socio cognitive unnoticeable traits (Alca'zar, 2012). At the work place people can be assorted due their positions in the hierarchy, their seniority, or education.

However (Ferdman \& Sagiv, 2012; Hellriege \& Slocum, 2011; Robbins \& Judge, 2013) believed that demographic features (gender, age, color, disability and finally race) were the principle of differentiation between humans even in workplace.

When it comes to Gender it was the oldest segregation. Women participation in the labor market began to increase after 1960s, but lower than males' in positions, salaries, development and promotion opportunities (Snell \& Bohlander, 2013).

In the last decades an optimistic view began to show; women took up an appropriate place in top management and engaged in strategic management process (Opstrup \& Villadsen, 2014). Even though in reality women representativeness didn't exceed third of males' numbers, participated just in specific domains (Dezso \& Ross, 2012), furthermore some of the research results (Abdullah, Ismail, \& Nachum, 2016) indicated that women strategic partnership didn't achieve considerable financial yield.

Another traditional dimension is Age. (Dessler, 2014) supposed that the increase in life expectations forced age diversity within organizations, different generations are to work beside each other. (Rabl \& Triana, 2014; Boehm, 
Kunze, \& Bruch, 2014) pointed that age diversity in any organization is unavoidable and beneficial too; old workers with long experience are good investment as they are knowledgeable, hard workers and loyal.

Colorism was rooted in Europe and U.S.A, people were categorized according to their skin color, hair type, and their physical appearance, the distinction was made between darkness and lightness (Hunter, 2007). The darker the person is, the less are the privileges he / she will get in the work place (Wilton, Sanchez, \& Chavez 2013; Hernandez, 2010).

In spite of the fact that discrimination is forbidden by law, it is sometimes manifested in countries where white are the majority (Block, Koch, Liberman, Merriweather, \& Roberson, 2011).

Disability had a special interest from regulators in the USA; the Americans with Disabilities Act of 1990 (ADA) was the foremost law aimed to dissolve any form of inequality and unfairness in hiring and compensating disable persons (Burkhauser, Schmeiser, \& Weathers , 2012).

Thanem (2008) indicated that this type of diversity requires more attention to go beyond what medical reports considered as disability. Moreover (Houtenville \& Kalargyrou 2012) referred to the cost and difficulties of preparing the appropriate physical and emotional work circumstances for this group without any harm. However organizations are likely to avail taxes credits and incentives, image and bright social responsibility record out of employing disable persons (Houtenville \&Kalargyrou, 2012).

When it comes to Race: it is a social term attributed to the original country of the individual, or his/ her belonging to a specific group of people (Horsford, 2014).

In 1976 the Federal Government of USA issued RRA (Race Related Act) to forbid legally any form of discriminating people due to their race. According to Brown and Erskine (2009) only the documented discretionary actions are taken into consideration as law violation, this show that the indirect oral cues are out of accountability.

(Simon, Kinias, O'Brien, Major, \& Bivolaru, 2013) admitted that race composed the largest percentage of discrimination; stereotyping made the issue wider and deeper.

\subsection{Workforce Diversity in Jordan}

The Jordanian law of labor No. 8 / 1996 organized the relationship between organizations' management and the employees, and guaranteed all the rights of them e.g., the article No. (13) explained in details the rights of disabled labors, while articles from (67) to (72) clarified the rights of working women.

Nationality is the major diversity in Jordanian workforce structure. Diversity was forced in its constituents by migrations. Since 1948 up to now Jordan was the shelter to the migrants from neighboring countries, (Al Musa $\&$ Yacoub, 2011). According to the formal statistics of 2015 the Jordanian government declared that there are more than one million and 300, 000 Syrian in Jordan; in addition to other nationalities, they are seeking to find any job under any conditions in the private sector.

To protect Jordanian workers, the labor law in article No. (12) prevent any organization from employing not Jordanians except for experts that are unique and their qualifications are not available nationally.

\subsection{Benefits of Diversity}

The theory of appraising the linkage between diversity and organizations' benefits is not an easy one; the effect is not direct and incremental over time (Svyantek \& Bolt 2004).

It was assumed that diversity reinforces organization's productivity, social facilitating and synergy between analogous groups to obtain collective goals (Luthans \& Doh, 2011; Robbins \& Judge, 2013).

(Richard, Murthi, \& Ismail, 2007) concluded that racial diversity has a positive effect on the performance of American service organizations.

(Rasul \& Rogger, 2015) reached to the point that diverse human resources enabled Nigerian public projects to be accomplished within the required quality and on time .

While (Richter, 2014; Pitts, 2009; Konopaske \& Ivancevish, 2004) found a direct linkage between diversity, innovation and creative problem solving; diverse people are mighty to generate unique ideas and proliferate alternatives.

(Parrotta, Pozzoli, \& Pytlikova, 2014) discovered a positive linkage between ethnic diversity and patents' number in the Danish technological sector. McGuirk and Jordan (2011) revealed that diversity stimulate creativity of the Irish Industrial organizations. While Yang and Konrad (2011) implied that diversity assisted in 
accelerating innovation in the Canadian large production organizations, Moreover Niebuhr (2010) found out that diversity resulted in increasing new products and the number of patents in German organizations. On the other hand (Roberson \& Park 2007; Bear, Rahman, \& Post, 2010) put insight on the role of employing minorities in promoting organizations' positive reputation, and in gaining stakeholders' satisfaction. In (Herring, 2009) findings there was a positive correlation between race diversity and customers' numbers and their purchasing volume.

\subsection{Disadvantages of Diversity}

From a pessimistic view many researchers proved that dissimilarity diminish group cohesion and minimize cooperation, and weaken organizations' performance. (Woehr, Arciniega, \& Poling, 2013) confessed that diversity activated conflict, destruct cohesion and team performance.

Furthermore diversity triggered stereotyping; gathering individuals into groups according to their culture, age, gender, color, race.. etc and opens the way to build incorrect expectations and prejudice ( Block et al., 2011; Dessler, 2014).

Otherwise diversity in any workplace increases the possibility of miscommunication, misunderstanding, perception problems and wrong interpretations, lack of trust, and different account of time urgency, particularly when making decisions (Luthans \& Doh, 2011; Konopaske \& Ivancevich, 2004).

(Cunningham 2009; Olsen \& Martins, 2012) visualized Diversity Management (DM) as the mechanism to maximize usefulness of diversity and diminish its disadvantages.

\section{Diversity Management}

\subsection{Diversity Management Objectives}

In its beginnings Diversity Management (DM) initiated to match the requirements of human rights movements, with no legal obligations (Sayers, 2012).

In 1960s the United States started the journey of issuing regulations against discriminations to form the DM introduction in U.S organizations; the objective was avoiding legal violation (Mkono, 2010). After then the concept developed; to be connected with planned actions of fair human resources strategies that aim to reach the optimal synergy between diverse human resources (Henry \& Evans 2007; Ravazzani, 2016) .

\subsection{Managing Diversity Effectively}

(Shen et al., 2009 ; believed that to maximize the benefits of having diverse human resources the attempts must go beyond the traditional approaches of celebrating differences; compliance to the state law, fair human resources strategies aren't any more enough.

DM should compromise set of strategies to embody minorities with the rest of the organization, embedded in all organization's activities (Kemper, et al., 2016).

(Minorities inclusion) is crucial in DM, as Sabharwal (2014) proposed, being a part in making serious decisions, participated in solving pivotal organizational problems.

\subsection{Diversity Management (DM) Results}

Wheeler (1998) noticed that it is not easy to measure DM results on productivity and monetary yield, (Ivancevich, \& Gilbert, 2000) confirmed the measurement difficulty, and think that shortage of adequate information increased the complexity of measurement. (Pitts , 2009) assured that managing diversity will have positive impact on minorities' morale, increase job satisfaction and accordingly their productivity.

(Cunningham 2009; Singh, Winkel, \& Selvarajan, 2013) confirmed the connection between DM and workers' performance.

(Yap, Holmes, Hannan, \& Cukier, 2010; Reynolds, Rahman, \& Bradetich, 2014) retrieved that DM energized employees to complete effectively and efficiently their tasks.

(Shen, D'Netto, \& Tang, 2010; Jauhari \& Singh 2013) assumed that DM activities foster workers' loyalty and commitment, inspire them for devoting extra efforts and time for the work benefit.

(Ashikali \& Groeneveld 2014; Sabharwal 2014) compiled DM effect with the feeling of inclusiveness and value added teamwork, and cooperation between organization members.

El- Masarwah (2011) tried to find the connection between diversity management and Nurses commitment in public and private hospitals in Riyadh, Saudi Arabia. His results confirmed the positive influence of DM on employees' attitudes and behavior that are reflected in loyal, faithful human resources. 
(Smith, Morgan, King, \& Peddie, 2012) supported the indoor advantages of DM and asserted the expansion of benefits to external stakeholders' satisfaction, reputation and organization's image.

\section{Research Methodology}

\subsection{Population and Sample}

Since most of diverse Human resources in Jordan are employed in the industrial sector, the researcher chose one of the industries that have sufficient numbers of non-Jordanian workforce (food industrial companies), which are operating at King Abdulla the second industrial city, where five of them agreed to be involved in the study, the sampling unit was the non-Jordanian workers in the five companies, 150 questionnaires were distributed, 143 of them were analyzed.

\subsection{The Study Tool}

The researcher depend on a 5 points likert scale questionnaire, which was set in the Arabic and in a simple language suits the educational level of the respondents, the questionnaire comprised three groups of questions; the first express the sample demographic information, the second took in diversity management strategies and the last part concerned with the dependent variable elements .

Justice between Jordanian workers and non-Jordanians was the substance of the questionnaire questions,

The answers were measured from strongly disagreed (1 point) to strongly agreed (5 points).

\subsubsection{Tool Validity}

To evaluate the questionnaire's validity, it was reviewed by a group of academic specialists in Human Resources Management; their correction notes were taken into account in reformulating the tool's questions.

\subsubsection{Tool Reliability}

To assess the internal consistency of the study questions; Cronbach's Alpha was calculated, the findings for all the independent and dependent variables and sub variable were above $70 \%$ and according to (Sekaran, 2003) The results indicated that the study's tool is reliable.

\section{Statistical Analysis Results}

(SPSS) version 21was used for analyzing the collected data.

Frequencies, percentage, arithmetic mean, standard deviation, one sample t test, and multiple regression were calculated to obtain the study's results as follows:

\subsection{Sampling Unit Characteristics}

By using frequencies and percentage It was found that $95 \%$ of the respondents were males, all of them are Arabs, all of them are working in non-managerial positions. When it comes to education $8 \%$ of them have university degree but from universities in their home countries, not exceeding B.A. $6 \%$ of them are not Muslims.

\subsection{The Results of Descriptive Analysis}

Table (1) demonstrates the total arithmetic means and total standard deviations of the sampling unit responses on the study's questions. Based on the mean scale (3) as a basis for comparison, it appears that the mean of staffing was the lowest (2.78), it is known that staffing procedures, are monitored by the Jordanian ministry of labor; any breach is not allowed. The means of the other HR strategies were above (3) and so for empowerment. Religious freedom gain the highest mean (3.99) this result is consistent with the community view in Jordan, where all religions are living together away from any discrimination.

Table 1. Descriptive statistics results

\begin{tabular}{lccccc}
\hline Independent Variable/ s & Mean & S. D & & Mean & S.D \\
\hline HR strategies & & & Empowerment & 3.53 & .684 \\
Staffing & 2.78 & 0.746 & & 3.99 & 0.578 \\
Development & 3.10 & 0.656 & Religious freedom & & \\
Compensation & 3.14 & 0.643 & & & \\
Performance appraisal & 3.29 & 0.862 & &
\end{tabular}

6.3 Hypotheses Testing

\subsubsection{The First Hypothesis}

Ho1: Jordanian food industry companies don't engage in diversity management activities (Justice in HR strategies, empowerment, and religious freedom). 
To test the first hypothesis, as clarified in table (2) One sample $t$ test, with test value $=3$ was calculated

The basis for accepting or rejecting the null hypothesis depends on $(t)$ calculated values, and ( $t$ ) significance level for each variable,

The results in the table exposed that the calculated $(t)$ values of all the sub independent variables were larger than (t) tabulated value (1.97) at 0.05 sig level, adding to that (t) sig level for all the variables were less than 0.05 . Which inferred that the surveyed organizations do engaged in diversity management strategies.

Table 2. One sample $t$ test test value $=3 \quad 95 \%$ Confidence Interval of the Difference

\begin{tabular}{lrrrrrrr}
\hline Variables & \multicolumn{1}{l}{ T value } & df & \multicolumn{2}{l}{$\begin{array}{l}\text { Sig. } \\
\text { (2-tailed) }\end{array}$} & $\begin{array}{l}\text { Mean } \\
\text { Differences }\end{array}$ & Lower & Upper \\
\hline HR strategies & $\mathbf{5 . 2 7 5}$ & 173 & $\mathbf{. 0 0 0}$ & $\mathbf{. 0 9 4 5 7}$ & $\mathbf{. 0 5 9 2}$ & $\mathbf{1 3 0 0}$ \\
& $\mathbf{1 3 . 0 6 7}$ & $\mathbf{1 7 3}$ & $\mathbf{. 0 0 0}$ & $\mathbf{0 . 3 9 5 1 1}$ & $\mathbf{0 . 3 3 5 4}$ & $\mathbf{0 . 4 5 4 8}$ \\
Empowerment & $\mathbf{3 2 . 1 9 4}$ & $\mathbf{1 7 3}$ & $\mathbf{. 0 0 0}$ & $\mathbf{. 9 8 5 6 3}$ & $\mathbf{9 2 5 2}$ & $\mathbf{1 . 0 4 6 1}$ \\
\hline
\end{tabular}

Tabulated $t$ value $=1.97, p=0.05$

6.3.2 The Second Hypothesis

Ho2: Diversity management strategies Have a positive influence on workers' (performance, cooperation, loyalty and commitment) .

The second main hypothesis was divided into 3 sub hypotheses. Multiple linear regression was used for hypotheses testing, with $0.05 \mathrm{p}$ value, and the hypothesis will be rejected if the calculated ( $\mathrm{t}$ sig value) is less than 0.05 .

Ho2 ${ }_{1}$ : Diversity management strategies have a positive influence on workers' performance.

Table (3) outlined the results of multiple linear regression of the impact of DM strategies (HRM, empowerment and religious freedom) on workers performance. The table manifested also the value of Pearson correlation (R) (.363) which expounded a positive association between the independent variables and the dependent, the value of $\left(R^{2}\right)(0.132)$ shows that $13.2 \%$ of the deviation in the dependent variable caused by the independents, for $F$ sig $(0.000)$ which was $<0.05$ affirmed that the model is suitable to continue the regression calculations. Referring to coefficients it is found that the calculated t values were as follows: (3.923) for human resources strategies with $0.00 \mathrm{sig}),(2.974)$ for empowerment with $0.003 \mathrm{sig}$, and (2.048) for religious freedom with $0.042 \mathrm{sig}$.

it is clear that the sig level for all the independent sub variables are less than .05 , The results inferred that all the DM strategies have an influence on workers performance, with disparity in effect as the values of Beta labeled that the highest effect was for HR Strategies as Beta $=(0.282)$, followed by empowerment as Beta $=(0.213)$ and the lowest effect was for religious freedom with (0.146) Beta value.

Table 3. Results of testing Ho2

\begin{tabular}{|c|c|c|c|c|}
\hline \multicolumn{5}{|c|}{ Model Summery \& ANOVA results } \\
\hline $\mathrm{R}$ & $\mathrm{R} 2$ & Adjusted R2 & F calculated & F sig \\
\hline 0.363 & .132 & 0.117 & 8.623 & $.000 \mathrm{~b}$ \\
\hline \multicolumn{5}{|c|}{ Coefficient } \\
\hline Sub-independent Variables & $\mathrm{B}$ & Beta & $\mathrm{T}$ - calculated & T sig \\
\hline Constant & 1.058 & & 2.177 & .031 \\
\hline Human resources strategies & .418 & .282 & 3.923 & .000 \\
\hline Empowerment & .188 & .213 & 2.974 & .003 \\
\hline Religious freedom & .127 & 146 & 2.048 & .042 \\
\hline
\end{tabular}

Ho22: Diversity management strategies have a positive influence on workers' cooperation.

Table (4) summarized the multiple regression results of DM strategies on workers cooperation

The value of $\mathrm{R}$ was $(0.210)$ articulated the positive weak nexus between DM strategies and workers cooperation, $\mathrm{R}^{2}$ was $(.04 \%)$ which set forth that independent variables don't explain more than this percentage of the deviation of workers cooperation. while the results of ( $t$ values) and their sig indicated that just (empowerment) had an influence on workers cooperation.

Whereas HR strategies neither religious freedom have an impact on workers cooperation, (t sig values) for both variables were $>0.05$. 
Table 4. Results of testing $\mathrm{Ho}_{2}$

\begin{tabular}{|c|c|c|c|c|}
\hline \multicolumn{5}{|c|}{ Model Summery \& ANOVA results } \\
\hline $\mathrm{R}$ & $\mathrm{R}^{2}$ & Adjusted R2 & F calculated & F sig \\
\hline $.210^{\mathrm{a}}$ & .044 & .027 & 2.613 & $.05^{\mathrm{b}}$ \\
\hline \multicolumn{5}{|c|}{ Coefficient } \\
\hline Sub-independent Variables & $\mathrm{B}$ & Beta & $\mathrm{T}$ - calculated & $\mathrm{T}$ sig \\
\hline Constant & 2.980 & & 5.001 & .000 \\
\hline Human resources strategies & -.091 & -.053 & -.697 & .487 \\
\hline Empowerment & .193 & .188 & 2.493 & \\
\hline Religious freedom & .065 & .064 & .856 & .393 \\
\hline
\end{tabular}

$\mathrm{Ho} 2_{3:}$ Diversity management strategies have a positive influence on workers' loyalty \& commitment.

The visualized values in Table (5) indicated that there is a weak positive correlation between the tested variables, due to $\mathrm{R}=0.294$.

It is appeared that the value of $\mathrm{F}$ sig (.012) is less than 0.05 which means that the model is adequate for regression test, while the values of ( $\mathrm{t}$ sig) proved that just religious freedom affects workers commitment and loyalty, $\mathrm{t}$ sig value was 0.03 less than 0.05 .

The numbers in the table elucidated that the other two sub variables (HR strategies and empowerment) had no effect on workers commitment and loyalty.

Table 5. Results of testing $\mathrm{Ho}_{3}$

\begin{tabular}{|c|c|c|c|c|}
\hline \multicolumn{5}{|c|}{ Model Summery \& ANOVA results } \\
\hline $\mathrm{R}$ & $\mathrm{R}^{2}$ & Adjusted R2 & F calculated & F sig \\
\hline $.249^{\mathrm{a}}$ & .062 & .045 & 3.745 & $.012^{\mathrm{b}}$ \\
\hline \multicolumn{5}{|c|}{ Coefficient } \\
\hline Sub-independent Variables & $\mathrm{B}$ & Beta & $\mathrm{T}$ - calculated & $\mathrm{T}$ sig \\
\hline Constant & 1.804 & & 2.744 & .007 \\
\hline Human resources strategies & .238 & .123 & 1.651 & .101 \\
\hline Empowerment & .027 & .024 & .315 & .753 \\
\hline Religious freedom & .250 & 221 & 2.970 & .003 \\
\hline
\end{tabular}

\section{Discussion and Recommendations}

The results of the arithmetic mean showed that the respondents were satisfied of DM strategies their organizations were engaged in, except for staffing. While the results of hypotheses testing exposed that all the DM strategies have an influence on workers performance, which go with the findings of Pitts (2009); Cunningham (2009) and Singh et al., (2013). Whereas simply empowerment has influenced workers cooperation, and just religious freedom has an impact on workers' loyalty and commitment.

These results didn't coincide with the results of (El- Masarwah 2011) Yap et al., (2010), Reynolds et al(Ashikali \& Groeneveld 2014).

Since the surveyed organizations are restricted with the labor of law when it comes to workers staffing, compensation, benefits and promotion, the companies' management can give more attention to other aspects than those. Good communication, open door policy, keeping the workers fully informed with what is expected of them, team work will surely make a difference in strengthening workers relationship with each other, and with the management.

Citizenship behavior commitment and loyalty can be spurred through involvement, equity and justice good treatment, and more freedom to express their suggestions, recognition programs with financial and non-financial rewards especially that their salaries are predetermined and controlled by law. in addition to providing them with suitable place for living.

All the above mentioned methods and others will be able to energize non-Jordanian workers' loyalty, faithful and commitment.

The researcher recommended conducting other researches in some other industries, using some other variables.

\section{Acknowledgement}

The author is grateful to Amman Arab University, Amman, Jordan, for the financial support granted to this research project.

\section{References}

Abdullah, S. N., Ismail, K. N., \& Nachum, L. (2016). Does Having Women on Boards Create Value? The Impact of Societal Perceptions and Corporate Governance in Emerging Markets. Strategic Management Journal, 
37(3), 466-476. https://doi.org/10.1002/smj.2352

Alcázar, M. F., Romero-Fernández, P. M., \& Sánchez-Gardey, G. (2012). Transforming human resource management systems to cope with diversity. Journal of Business Ethics, 107(4), 511-531. https://doi.org/10.1007/s10551-011-1061-0

Al-Musa, M., \&Yacoub, M. (2011). Breaking the Silence: Irregular Migrant Workers in Jordan: Between Marginalization and Integration.

Ashikali, T., \& Groeneveld, S. (2015). Diversity management for all? An empirical analysis of diversity management outcomes across groups. Personnel Review, 44(5), 757-780.

https://doi.org/10.1108/PR-10-2014-0216

Bear, S., Rahman, N., \& Post, C. (2010). The impact of board diversity and gender composition on corporate social responsibility and firm reputation. Journal of Business Ethics,97(2), 207-221. https://doi.org/10.1007/s10551-010-0505-2

Block, C. J., Koch, S. M., Liberman, B. E., Merriweather, T. J., \& Roberson, L. (2011). Contending with stereotype threat at work: A model of long-term responses. The Counseling Psychologist, 39(4), 570-600. https://doi.org/10.1177/0011000010382459

Boehm, S. A., Kunze, F., \& Bruch, H. (2014). Spotlight on age-diversity climate: The impact of age-inclusive HR practices on firm-level outcomes. Personnel Psychology, 67(3), 667-704.

Brown, A., \& Erskine, A. (2009). A Qualitative study of judgments in race discrimination employment cases, Law \& Policy, 31(1), 142-159. https://doi.org/10.1177/0011000010382459

Burkhauser, R. V., Schmeiser, M. D., \& Weathers, R. R. (2012). The importance of anti-discrimination and workers' compensation laws on the provision of workplace accommodations following the onset of a disability. ILR Review, 65(1), 161-180. https://doi.org/10.1177/001979391206500109

Cunningham, G. B. (2009). The moderating effect of diversity strategy on the relationship between racial diversity and organizational performance. Journal of Applied Social Psychology, 39(6), 1445-1460. https://doi.org/10.1111/j.1559-1816.2009.00490.x

Dessler, G. (2014). Fundamentals of human resource management. (3rd ed.) Harlow, Pearson Education Limited.

Dezso, C. L., \& Ross, D. G. (2012). Does female representation in top management improve firm performance? A panel data investigation. Strategic Management Journal, 33(9), 1072-1089. https://doi.org/10.1002/smj.1955

El-Masarwa, A. (2011) Impact of Managing Human Resources Diversity in the Nursing Sector on Organizational Commitment: A Comparative Study Between Public and Private Hospitals in Riyadh City, (Unpublished Doctoral dissertation). Amman Arab University, Amman, Jordan.

Ferdman, B. M., \& Sagiv, L. (2012). The Value of Connecting Diversity in Organizations and Cross-Cultural Work Psychology Through Dialogue and Multiplicity. Industrial and Organizational Psychology, 5(3), 373-379. https://doi.org/10.1111/j.1754-9434.2012.01454.x

Hellriege, D., \& Slocum, J. W. (2011). Organizational behavior, (13th ed.), Mason OH, South Western Cengage Learning.

Henry, O., \& Evans, A. J. (2007). Critical review of literature on workforce diversity. African Journal of Business Management, 1(4), 72-76. http://www.academicjournals.org/ajbm

Hernandez, T. K. (2010). Employment Discrimination in the Ethnically Diverse Workplace. Judges J. 49(33), 33-37. http://ir.lawnet.fordham.edu/faculty_scholarship/14

Herring, C. (2009). Does diversity pay? Race, gender, and the business case for diversity. American Sociological Review, 74(2), 208-224. https://doi.org/10.1177/000312240907400203

Horsford, S. D. (2014). When race enters the room: Improving leadership and learning through racial literacy. Theory Into Practice, 53(2), 123-130. https://doi.org/10.1080/00405841.2014.885812

Houtenville, A., \& Kalargyrou, V. (2012). People with disabilities: Employers' perspectives on recruitment practices, strategies, and challenges in leisure and hospitality. Cornell Hospitality Quarterly, 53(1), 40-52. https://doi.org/10.1177/1938965511424151

Hunter, M. (2007). The persistent problem of colorism: Skin tone, status, and inequality. Sociology 
Compass, 1(1), 237-254. https://doi.org/10.1111/j.1751-9020.2007.00006.x

Ilmakunnas, P., \& Ilmakunnas, S. (2011). Diversity at the workplace: Whom does it benefit? De Economist, 159(2), 223-255. https://doi.org/10.1007/s10645-011-9161-x

Ivancevich, J. M., \& Gilbert, J. A. (2000). Diversity management: Time for a new approach. Public personnel management, 29(1), 75-92. https://doi.org/10.1177/009102600002900106

Jauhari, H., \& Singh, S. (2013). Perceived diversity climate and employees' organizational loyalty. Equality, Diversity and Inclusion: An International Journal, 32(3), 262-276.

https://doi.org/10.1108/EDI-12-2012-0119

Jordanian Labor Law. (1996). No. 8 of 1996. Retrieved from www.mol.gov.jo

Kemper, L. E., Bader, A. K., \& Froese, F. J. (2016). Diversity management in ageing societies: A comparative study of Germany and Japan. Management Revue, 27(1/2), 29.

Konopaske, R., \& Ivancevich, J. M. (2004). Global management and organizational behavior: Text, readings, cases, and exercises.Boston, McGraw Hill.

Luthans, F., \& Doh, J. P. (2012). International management: Culture, strategy, and behavior. (8th ed.). New York, NY: McGraw-Hill Irwin.

McGuirk, H., \& Jordan, D. (2012). Local labour market diversity and business innovation: evidence from Irish manufacturing businesses. European Planning Studies, 20(12), 1945-1960. https://doi.org/10.1080/09654313.2012.722918

Mkono, M. (2010). In defence of hospitality careers: Perspectives of Zimbabwean hotel managers. International Journal of Contemporary Hospitality Management, 22(6), 858-870. https://doi.org/10.1108/09596111011063124

Niebuhr, A. (2010). Migration and innovation: Does cultural diversity matter for regional R\&D activity?. Papers in Regional Science, 89(3), 563-585. https://doi.org/10.1111/j.1435-5957.2009.00271.x

Olsen, J. E., \& Martins, L. L. (2012). Understanding organizational diversity management programs: A theoretical framework and directions for future research. Journal of Organizational Behavior, 33(8), 1168-1187. https://doi.org/10.1002/job.1792

Opstrup, N., \& Villadsen, A. R. (2015). The right mix? Gender diversity in top management teams and financial performance. Public Administration Review, 75(2), 291-301. https://doi.org/10.1111/puar.12310

Pant, J. J., \& Vijaya, V. (2015). Challenges in Diversity Management: A Case Study of Medi Health Systems. South Asian Journal of Management, 22(1), 159.

Parrotta, P., Pozzoli, D., \& Pytlikova, M. (2014). The nexus between labor diversity and firm's innovation. Journal of Population Economics, 27(2), 303-364. https://doi.org/10.1007/s00148-013-0491-7

Pitts, D. (2009). Diversity management, job satisfaction, and performance: Evidence from US federal agencies. Public Administration Review, 69(2), 328-338. https://doi.org/10.1111/j.1540-6210.2008.01977.x

Rabl, T., \& del Carmen, T. M. (2014). Organizational value for age diversity and potential applicants' organizational attraction: Individual attitudes matter. Journal of Business Ethics, 121(3), 403-417. https://doi.org/10.1007/s10551-013-1729-8

Rasul, I., \& Rogger, D. (2015). The impact of ethnic diversity in bureaucracies: Evidence from the Nigerian civil service. American Economic Review, 105(5), 457-461. https://doi.org/10.1257/aer.p20151003

Ravazzani, S. (2016). Understanding approaches to managing diversity in the workplace: an empirical investigation in Italy. Equality, Diversity and Inclusion: An International Journal,35(2), 154-168. https://doi.org/10.1108/EDI-08-2014-0062

Reynolds, D., Rahman, I., \& Bradetich, S. (2014). Hotel managers' perceptions of the value of diversity training: an empirical investigation. International Journal of Contemporary Hospitality Management, 26(3), 426-446. https://doi.org/10.1108/IJCHM-02-2013-0079

Richard, O. C., Murthi, B. P., \& Ismail, K. (2007). The impact of racial diversity on intermediate and long-term performance: The moderating role of environmental context. Strategic Management Journal, 28(12), 1213-1233. https://doi.org/10.1002/smj.633

Richter, D. (2014). Demographic change and innovation: The ongoing challenge from the diversity of the labor 
force. Management Revue, 166-184. http://dx.doi.org/10.1688/mrev-2014-03-Richter

Robbins , S. P., \& Judge, T. A . (2013), Organizational behavior (15th ed.). Boston, Pearson Prentice-Hall.

Robbins, S. P., \&Coulter, M. (2012), Management (11th ed.) . Boston, Pearson Prentice-Hall.

Roberson, Q. M., \& Park, H. J. (2007). Examining the link between diversity and firm performance: The effects of diversity reputation and leader racial diversity. Group \& Organization Management, 32(5), 548-568. https://doi.org/10.1177/1059601106291124

Sabharwal, M. (2014). Is diversity management sufficient? Organizational inclusion to further performance. Public Personnel Management, 43(2), 197-217. https://doi.org/10.1177/0091026014522202

Sayers, J., \& Ang, E. K. (2012). Managing Diversity. http// bookboon.com.

Sekaran, U. (2003)Research methods for business: A skill building approach (4 th ed.). New York , NY. John Wiley \& Sons.

Shen, J., Chanda, A., D'netto, B., \& Monga, M. (2009). Managing diversity through human resource management: An international perspective and conceptual framework. The International Journal of Human Resource Management, 20(2), 235-251. https://doi.org/10.1080/09585190802670516

Shen, J., D'Netto, B., \& Tang, J. (2010). Effects of human resource diversity management on organizational citizen behaviour in the Chinese context. The International Journal of Human Resource Management, 21(12), 2156-2172. https://doi.org/10.1080/09585192.2010.509622

Simon, S., Kinias, Z., O'Brien, L. T., Major, B., \& Bivolaru, E. (2013). Prototypes of discrimination: How status asymmetry and stereotype asymmetry affect judgments of racial discrimination. Basic and Applied Social Psychology, 35(6), 525-533. https://doi.org/10.1080/01973533.2013.823620

Singh, B., Winkel, D. E., \& Selvarajan, T. T. (2013). Managing diversity at work: Does psychological safety hold the key to racial differences in employee performance?. Journal of Occupational and Organizational Psychology, 86(2), 242-263. https://doi.org/10.1111/joop.12015

Smith, A. N., Morgan, W. B., King, E. B., Hebl, M. R., \& Peddie, C. I. (2012). The ins and outs of diversity management: The effect of authenticity on outsider perceptions and insider behaviors. Journal of Applied Social Psychology, 42(S1), E21-E55. https://doi.org/10.1111/j.1559-1816.2012.01021.x

Snell, S. A., \& Bohlander, G. W. (2013). Managing human resources (16 th ed.). South Western, Cengage Learning.

Svyantek, D. J., \& Bott, J. (2004). Received wisdom and the relationship between diversity and organizational performance. International Journal of Organizational Analysis, 12(3), 295-317.

Thanem, T. (2008). Embodying disability in diversity management research. Equal Opportunities International, 27(7), 581-595. https://doi.org/10.1108/02610150810904292

Wheeler, M. L. (1998). Measuring diversity: A strategy for organizational effectiveness. Employment Relations Today, 25(1), 61-68. https://doi.org/10.1002/ert.3910250107

Wilton, L. S., Sanchez, D. T., \& Chavez, G. F. (2013). Speaking the language of diversity: Spanish fluency, White ancestry, and skin color in the distribution of diversity awards to Latinos. Basic and Applied Social Psychology, 35(4), 346-359. https://doi.org/10.1080/01973533.2013.803969

Woehr, D. J., Arciniega, L. M., \& Poling, T. L. (2013). Exploring the effects of value diversity on team effectiveness. Journal of Business and Psychology, 28(1), 107-121. https://doi.org/10.1007/s10869-012-9267-4

Yang, Y., \& Konrad, A. M. (2011). Diversity and organizational innovation: The role of employee involvement. Journal of Organizational Behavior, 32(8), 1062-1083. https://doi.org/10.1002/job.724

Yap, M., Holmes, M. R., Hannan, C. A., \& Cukier, W. (2010). The relationship between diversity training, organizational commitment, and career satisfaction. Journal of European industrial training, 34(6), 519-538. https://doi.org/10.1108/03090591011061202

\section{Copyrights}

Copyright for this article is retained by the author(s), with first publication rights granted to the journal.

This is an open-access article distributed under the terms and conditions of the Creative Commons Attribution license (http://creativecommons.org/licenses/by/4.0/). 